\title{
IS-06
}

\section{自動車ホイール形状因子の空力感度分析 \\ Aerodynamic Sensitivity Analysis of Wheel Shape Factors on Passenger Cars}

○正 廣瀬 健一 ${ }^{* 1}$, 川俣 英之*1, 大島 宗彦*1

Kenichi HIROSE*1, Hideyuki KAWAMATA*1, Munehiko OSHIMA*1

*1 日産自動車株式会社 Nissan Motor Co., Ltd.

Key Words : Passenger cars, Aerodynamic drag, Wind tunnel test, Wheel, Multiple regression analysis

\section{緒言}

自動車のタイヤ，ホイール，ホイールハウスが，車両全体の空気抵抗に占める割合は約 $25 \%$ ときい(1). これ ら部品の中でホイールは造形部品であるため, デザインと空力性能の両立が重要である。これまでの研究では, Landström らがセダンを対象にホイール形状因子の $\mathrm{C}_{\mathrm{D}}$ 感度を明らかにした(2). しかし，著者らの知る限り，車型 違い及び外観形状違いが，ホイール形状因子の $\mathrm{C}_{\mathrm{D}}$ 感度に与える影響について調べた研究はない。そこで今回， 車型違い及び外観形状違いを考慮した, ホイール形状因子の $\mathrm{C}_{\mathrm{D}}$ 感度を明らかにすることを目的に, セダンと SUV を対象にリヤフェンダ形状 2 種類で風洞実験を行い, その実験結果を重回帰分析した (3).

\section{手法}

風洞実験は，フランスにある GIE Soufflerie Aeroacoustiques Automobiles (S2A) で実施した. 空力 6 分力は，風速 $140 \mathrm{~km} / \mathrm{h}$, 偏摇角 0 度の条件にて，5 ベルト式 6 分力天科装置で計測した。調査対象は, 車型違いとしてセダン とSUVの 2 車型，外観形状違いとしてリヤフェンダ形状 2 種類の，計 4 ケースを調査した. ホイールサイズは 全て 17 インチであり，セダンと SUVのそれぞれで 15 種類の異なるホイール仕様で $\mathrm{C}_{\mathrm{D}}$ を計測した。その計測結 果を重回帰分析することにより，ホイール形状因子の $\mathrm{C}_{\mathrm{D}}$ 感度を明らかにした。具体的には前述の 4 ケースのデ 一タセットを用いて，4 種類の重回帰分析を行った. 重回帰式の目的変数を基点ホイールからの $\mathrm{C}_{\mathrm{D}}$ 変化とし, 説 明変数をホイール形状因子とした。説明変数の候補として調査したホイール形状因子の数は 14 個である.

\section{結果}

重回帰分析の結果，セダンと SUV のそれぞれで，4 つのホイール形状因子の $\mathrm{C}_{\mathrm{D}}$ 感度が高いことが分かった. また，セダンと SUV の両車型で，リヤフェンダ形状が異なっても $\mathrm{C}_{\mathrm{D}}$ 感度の高いホイール形状因子は同じであっ た. 求めた重回帰式の予測精度を確認寸るため, 重回帰分析では用いなかった別ホイールにて $\mathrm{C}_{\mathrm{D}}$ 変化の実測值 と予測值を比較した. 結果，4 ケースとも $\mathrm{C}_{\mathrm{D}}$ 変化の傾向をとらえられており，本予測式を用いた $\mathrm{C}_{\mathrm{D}}$ 低減検討が 可能であることが分かった.

\section{結言}

・車型やリヤフェンダ形状に寄らず $\mathrm{C}_{\mathrm{D}}$ 低減感度の高いホイール形状因子を明らかにした。

・ ホイール形状因子を入力值とした $\mathrm{C}_{\mathrm{D}}$ 低減効果予測式を導出し, 本予測式を用いた $\mathrm{C}_{\mathrm{D}}$ 低減検討を可能とした.

\section{文献}

(1) Wickern, K., Zwicker, M., and Pfadenhauer, M., "Rotating Wheels - Their Impact on Wind Tunnel Test Techniques and on Vehicle Drag Results," SAE Technical Paper 970133, 1997.

(2) Landström, C., Josefsson, L., Walker, T., and Löfdahl, L., "An Experimental Investigation of Wheel Design Parameters with Respect to Aerodynamic Drag," 8th FKFS Conference, 2011.

(3) Hirose, K., Kawamata, H., and Oshima, M., "Aerodynamic Sensitivity Analysis of Wheel Shape Factors," SAE Technical Paper 2019-01-0667, 2019. 